\title{
PRESS OF THE GERMAN MINORITY IN POLAND IN 1989-2017 Grzegorz Rachwat?
}

\begin{abstract}
The aim of this article is to characterize the German minority press market in Poland in the period of 1989-2017. The article constitutes a discussion regarding terms that are key for the undertaken subject, i.e., "national minority", "ethnic minority" and "the press of national and ethnic minorities"; furthermore, a typology of the functions of these media is presented. The analysis covered the socio-political framework of the functioning of minority media, as well as legal regulations at the level of publishing activities of national and ethnic minorities and the support of the Polish state towards publishing initiatives of minorities from 1989 to the present day. The article also constitutes an overview of German minority press issued in 1989 - 2017 in the Polish state. Characteristics of the periodicals contain information about their creation, presentation of graphic layout and publishing formula, as well as the thematic profile of the published contents. Approximating the German minority in Poland, the author attempts to answer the question of what role the German press once played in the Polish German society, and what is its role today, as well as who are the recipients of the German press in Poland today, what is its current condition and what are the prognoses for its development in the short and longer term. The conducted research applied technical analysis and analysis of press content. The study uses a number of sources. These include state documents published in journals of law, in various types of bulletins, reviews and in the on-line version.
\end{abstract}

Keywords: press, media, minority

\section{Introduction}

The debate on national and ethnic issues in the Polish state after World War II remained in a frozen state. This resulted from the realities of the political system.

Drawing attention of the Polish state to national and ethnic minorities in the 90s conditioned the process of democratization of public life. Implementation of subsequent demands of minorities has made real the redefinition of the state's policy towards these communities [MSWiA, 2007, on-line, Raport dotyczący..., p. 53, 87, 101-102]. Assistance provided to the national minorities' magazines in Poland, guaranteeing them economic stability, should be perceived as the choice of the state's path of acceptance and tolerance towards minorities.

An important factor influencing the development of the press of national and ethnic minorities in Poland was simultaneous activation of the minorities themselves. For them, the means of social communication have been and are one of the most important

\footnotetext{
Grzegorz Rachwał, Ph.D. student, University of Information Technology and Management in Rzeszow (Poland), e-mail: gr.rachwal@wp.pl
} 
instruments to strengthen identity awareness. They also play a significant role in the creation of ties between, sometimes territorially dispersed, minority communities. They constitute a forum for conducting polemics and working out a common minority stance on fundamental issues in the area of social and political life at the local and national level [Berdychowska, 1995, p. 4; Mieczkowski, 2012, p. 124].

The existence of the German minority in the media sector in Poland after 1989 can be called two-pillar. On the one hand, it has gained participation in the air time in public media and commercial stations, and, secondly, it has established its own publishing houses [Jas-Koziarkiewicz, 2009, p. 111-112]. If we compare the scale of activity within these two spheres, it should be noted that for this minority, this second aspect of functioning in the media is of fundamental importance.

The aim of the article is to characterize the press sector of the German minority in Poland in the period 1989-2017. The starting point is the explanation of the key concepts for the subject matter, i.e., "national minority", "ethnic minority" and "press of national and ethnic minorities" as well as the presentation of the typology of the functions of these media. The analysis covers the socio-political framework for the functioning of minority media in the Polish state and the applicable legal regulations on the publishing activities of national and ethnic minorities, as well as the Polish state's support for minority publishing initiatives from 1989 to the present day. Particular attention is devoted to the publishing offer in the press sector addressed to the German minority in the Polish state over the years 1989 - 2017. Characteristics of the periodicals contain information about their creation, presentation of graphic layout and publishing formula, as well as the thematic profile of the published contents. The article also discusses the extent to which the press of national and ethnic minorities determines the formation of the social communication system of minorities. Reflections on the impact of the structure of the German minority community (numerical, demographic, linguistic, and social) on the publishing offer addressed to it precede conclusions regarding the condition of the German press in Poland and the predictions for its development in the short and long term.

The conducted research applied technical analysis and analysis of press content. The study uses a number of sources. These include state documents published in journals of law, in various types of bulletins, reviews and in on-line versions.

\section{Understanding of the concepts: "national minority", "ethnic minority"}

The term "national minority" is a subject of research and finds application in numerous scientific disciplines, e.g.: social sciences, political sciences, law, anthropology and ethnology, as well as demography and statistics [Kojder, 1998, p 259-264]. Nevertheless, scientists who study this field point towards various definitions. Hence, the notion is open to more than one interpretation and multidimensional [Jas-Koziarkiewicz, 2009, p. 21-26; Kruszewski, 2008, p. 43-44; Mieczkowski, 2007, p. 10-11].

Polish legislation has also been unable to develop a coherent interpretation of the concept of national minority for a long time. Protection of minorities was based on the protection of Polish citizens who held the right to self-determine their nationality [Jas-Koziarkiewicz, 2009, p. 25]. This state of affairs was regulated by the Act on National and Ethnic Minorities and the Regional Languages of January 6, 2005; according to the adopted law, a national minority is understood as a community of citizens of the Polish state, identified by the following determinants: it is less numerous than the rest of the population of the Republic of Poland; it significantly differentiates itself from other citizens through language, culture or tradition; it strives to preserve its language, culture or tradition; it is aware of its own historical national community and is focused on its expression and protection; it identifies itself with the nation organized within its own country. Pursuant to the provisions of the Act, it is also necessary that ancestors [of the group] have inhabited the present territory of the Republic of Poland for at least 100 years. The Act 
also distinguishes a list of legally recognized and protected minorities. These include: Belarussians, Czechs, Lithuanians, Germans, Armenians, Russians, Slovaks, Ukrainians and Jews. It should be noted that the provisions of the Act also define the concept of ethnic minority. An ethnic minority within the meaning of the Act is characterized by the fact that it does not identify [itself] with the nation organized within its own country. The remaining grounds for recognition as an ethnic minority are the same as in the case of national minorities. According to art. 2 para. 3., ethnic minorities in the territory of the Republic of Poland include: Karaims, Lemkos, Romanies and Tartars.

\section{Determinants of the German minority press market in Poland}

\subsection{Media of national and ethnic minorities - definition and typology of func- tions}

The discussed issue requires clarification of the concept media of national and ethnic minorities.

The media of national minorities are defined as one of the types of community media characterized by low coverage, located outside the mainstream of mass media, strongly integrated with organizations or minority societies, performing an important task in the process of maintaining and strengthening the sense of identity of individuals and communities by cultivating national and/or ethnic traditions. In most cases, they are founded and subsidized by representatives of minorities and are also intended for them, however, they are also available to the rest of society. Most often, they are not focused on activities aimed at achieving financial profits [Klimkiewicz, 1997, p. 48; Mieczkowski, 2012, p. 119].

When defining the functions of the media of national and ethnic minorities, press experts most often use the catalog drawn up in the course of work established by UNES$\mathrm{CO}$ in 1977 of the International Commission for the Study of Communication Problems. It lists the following functions:

- information: collecting, storing, processing and publishing information, facts, images, texts, opinions and comments that help to better understand and adapt their activity to evolving social conditions and improve decision-making processes;

- socialization: providing communities and/or individuals with data and patterns essential for proper functioning within society;

- motivation: awakening the desire to strive for group and individual goals;

- debates and discussions: the data provided is to constitute a starting point for making efforts to reach agreement or consensus, triggering curiosity and willingness to act, aimed at developing remedies for disputable or problematic issues in the local, national or international environment;

- education: providing information that stimulates the intellectual development of the individual and the community concerned;

- culture development: popularization of art and its achievements, nurturing cultural heritage, stimulating creative and artistic ambitions of the individual;

- entertainment: promoting all areas of art that provide the individual and society with entertainment;

- integration: providing information about individuals, nations and communities, enabling agreement and facilitating the perception and understanding of factors conditioning different opinions, aspirations and living conditions [Jas-Koziarkiewicz, 2009, p. 85-88].

\subsection{German minority in Poland}

Germans are the most numerous national minority that inhabits the borders of the Republic of Poland. During the National Population and Housing Census completed in 
2011, 144,238 Polish citizens declared their German identity. Territorial distribution of persons with German nationality is the highest in the Opole (53\%), Silesian (nearly $24 \%$ ) and Warmian-Masurian (around 3\%) voivodships. It should be added that the territorial distribution of the population with German identity coincides with the declarations of active German language skills [MSWiA, 2018, on-line, Charakterystyka mniejszości...].

The results of the census showed a tendency to increase the number of people perceiving themselves as Silesians and the reduction of German declarations, which may in the long run find a negative reflection in the amount of financial support provided to minorities by the Federal Republic of Germany [Urban, 2018, on-line, Media mniejszości...; Sakson, 2012, p. 1-5].

There is currently one representative of the German minority in the Polish parliament - Ryszard Galla. He obtained the parliamentary mandate from the electoral list of the German minority committee [Kancelaria Sejmu, 2018, on-line: Posłowie].

In communes and poviats inhabited by the German community, minority representatives play an important role in local government authorities, administering some of the local government units independently or in cooperation with other committees [MSWiA, 2018, on-line, Charakterystyka mniejszości...].

\subsection{Legal conditions.}

The basic act of the Republic of Poland guarantees, among others, one of the fundamental human rights, i.e., one to obtain and disseminate information (Art. 54 (1)). The constitution includes a ban on the licensing of publishing activity and introduction of preventive censorship. The right to disseminate and exchange information in the minority language which is legally enforceable under the law on national minorities (Art. 8) plays a significant role for the issue discussed.

Until 2005, the activity of minorities in the area of printed media was based on practical assumptions. One of them was to determine the rule of subsidizing publishing activity from public funds. In the event that a minority published only one title (in Polish, or a minority or foreign language), the financial resources for its functioning were provided by the competent ministry, in whole or in part. If, on the other hand, a larger number of magazines were issued, as was the case with the German minority, subsidies were granted at a lower level [ MSWiA, 2007, online, Raport dotyczący..., p. 53].

The direct imposition of the obligation on the state to support the economic activity of publishing minorities took place in the Act on National Minorities (Art. $18 \mathrm{sec}$. 2 item 3 ). According to the adopted solution, public authorities are obliged to support activities aimed at protecting, preserving and developing the cultural identity of minorities. This support can be implemented in the form of targeted or objective subsidies, including for the purpose of publishing books, magazines, periodicals and leaflets in minority languages or in Polish, in printed form and in other image and sound recording techniques.

It should therefore be emphasized that state support was directed to national minorities earlier than adopted by way of a law.

\subsection{Budget subsidies}

Maintaining the cultural heritage of minorities in Poland is possible thanks to substantial financial support from the state. It manifests itself directly and indirectly. Among the first can be included, inter alia, the provision of the zero VAT rate on minority magazines by means of the Act of 11 March 2004 on the Value Added Tax to the end of 2007. Direct support is visible in the form of a subsidy:

1. for basic cultural activities:

- maintaining artistic groups (choirs, dance groups, etc.);

- education of the young generation (seminars, courses, workshops, etc.);

- spreading knowledge about national minorities in Poland; 
2. for cultural activities through presentations:

- in the form of festivals, reviews of artistic achievements, contests, etc.;

- the culture of national minorities in the Polish media and abroad;

3. for publishing, aimed at preserving the minority language through financial support in publishing low-circulation magazines and books. [MSWiA, 2018, on-line, Dotacje...]

In 2017, Poland spent approximately PLN 14.738 .930 on the preservation and development of cultural activities of all minorities. Financial assistance was received by about 30 periodicals of minorities. The size of the subsidy addressed to the German minority magazines provided by the Department of Culture of Ethnic Minorities in the Ministry of Culture in selected years is shown below:

\begin{tabular}{|c|c|c|c|c|c|c|c|c|c|c|c|c|}
\hline \multirow{2}{*}{$\begin{array}{c}\text { NAME } \\
\text { OF ENTITY }\end{array}$} & \multirow{2}{*}{ TITLE } & \multirow{2}{*}{$\begin{array}{l}\text { PLACE } \\
\text { OF ISSUE }\end{array}$} & \multicolumn{10}{|c|}{ Number of prints in years (in thous. copies) } \\
\hline & & & 1998 & 2000 & 2004 & 2010 & 2011 & 2012 & 2013 & 2014 & 2015 & 2017 \\
\hline $\begin{array}{l}\text { German Working } \\
\text { Community "Rec- } \\
\text { onciliation and } \\
\text { Future" }\end{array}$ & "Hoffnung" & Katowice & 12 & 20 & - & - & - & - & - & - & - & - \\
\hline $\begin{array}{l}\text { Seminar named } \\
\text { after Joseph von } \\
\text { Eichendorff }\end{array}$ & $\begin{array}{l}\text { "Z e s z y t y } \\
\text { Eiche ndorf- } \\
\text { fa/ Eichen- } \\
\text { dorff-Hefte" }\end{array}$ & Opole & 24 & 30 & 36 & 40.5 & 40.4 & 35 & - & - & 23.4 & 23.4 \\
\hline $\begin{array}{l}\text { Mazurian As- } \\
\text { sociation of the } \\
\text { Polish-German } \\
\text { Union in Olsztyn }\end{array}$ & $\begin{array}{l}\text { "Masurische } \\
\text { Storchenpost" }\end{array}$ & Olsztyn & 12 & 22 & 20 & 20 & 20 & 20 & 20 & 19 & 22 & 20 \\
\hline $\begin{array}{l}\text { Association of } \\
\text { the German Mi- } \\
\text { nority in Olsztyn }\end{array}$ & $\begin{array}{l}\text { "Allensteiner } \\
\text { Nachrichten" }\end{array}$ & Olsztyn & - & - & - & 9.3 & 9.5 & 11.8 & 11.6 & 11 & 11.6 & 11.6 \\
\hline $\begin{array}{l}\text { Union of German } \\
\text { Associations in } \\
\text { Warmia-Masuria } \\
\text { Province }\end{array}$ & $\begin{array}{l}\text { "Mitteilungs- } \\
\text { blatt" }\end{array}$ & Olsztyn & 11 & 15 & 18 & 21 & 22.2 & 23.7 & 23.2 & 22 & 22 & 22 \\
\hline $\begin{array}{l}\text { A s s o c i a t i o n } \\
\text { of German So- } \\
\text { cio-Cultural Or- } \\
\text { ganizations in } \\
\text { Poland }\end{array}$ & $\begin{array}{l}\text { "Wochenblatt. } \\
\text { pl" }\end{array}$ & Opole & 200 & 280 & 380 & 430 & 430 & 430 & 430 & 411.5 & 411.5 & 411.5 \\
\hline $\begin{array}{l}\text { Socio-Cultural } \\
\text { Association of } \\
\text { the German Mi- } \\
\text { nority in Zielona } \\
\text { Góra }\end{array}$ & $\begin{array}{l}\text { "Miesięcznik } \\
\text { Zielonogórski } \\
-\quad \text { Grünberger } \\
\text { Monatsblatt }\end{array}$ & $\begin{array}{l}\text { Z i e l o n a } \\
\text { Góra }\end{array}$ & - & - & - & - & 4 & 4 & 4 & 4 & 4 & 4 \\
\hline $\begin{array}{lr}\text { German } & \text { So- } \\
\text { cio-Cultural } & \text { Or- } \\
\text { ganization } & \text { in } \\
\text { Wrocław } & \\
\end{array}$ & $\begin{array}{l}\text { "Niederschle- } \\
\text { sische Infor- } \\
\text { mationen" }\end{array}$ & Wrocław & - & - & - & - & - & - & - & 4.5 & 4.4 & 4.6 \\
\hline $\begin{array}{l}\text { House for Pol- } \\
\text { ish-German Co- } \\
\text { operation in Gli- } \\
\text { wice }\end{array}$ & $\begin{array}{l}\text { "KEKS für die } \\
\text { P a u s e / n a } \\
\text { przerwę" }\end{array}$ & Gliwice & - & - & - & - & - & - & - & - & 23.2 & 24 \\
\hline $\begin{array}{l}\text { Association of } \\
\text { libraries, media, } \\
\text { culture and sci- } \\
\text { ence }\end{array}$ & $\begin{array}{l}\text { "Die Heimat- } \\
\text { kirche. Glaube } \\
\text { und Kultur in } \\
\text { Schlesien" }\end{array}$ & Opole & - & - & - & - & - & - & 6.2 & 5.5 & 6.5 & 14 \\
\hline
\end{tabular}

[MSWiA, 2018, on-line, Dotacje...]

In the case of the German minority, subsidies are not only directed from the Polish state, but also from the Federal Republic of Germany. For this reason, Polish subsidies 
are at a lower level than funds allocated to other minorities. The leaders of the German minority in Poland make critical remarks about this solution. In their opinion, the amount of financial support should be determined in direct proportion to the size of the minority, without taking into account other factors [Mieczkowski, 2001, p. 165; Jas-Koziarkiewicz, 2009, p. 104].

\section{Press of the German minority after 1989}

Restrictions in the Polish People's Republic thwarted the expression of needs and the cultivation of the national traditions of the German minority. After 1989, they caused the greater "intensification" of Germanness along with the democratization of public life in Poland. In 1990, they following were released simultaneously: "Masurische Storchenpost" (Masuria Stork Post) in Olsztyn as an organ of the Mazurian Association, and in Silesia "Oberschlesische Nachrichten" (Upper Silesian News) as an addition to the local daily newspaper "Trybuna Opolska" (Opole Tribune) [Jas-Koziarkiewicz, 2009, p. 111-114; Mieczkowski, 2007, p. 304].

The panorama of periodicals addressed to the German minority community in Poland from the perspective of 29 years after the transformation of the political system is wide.

It should be emphasized that the systemic transformation brought the process of overtaking magazines by associations of national and ethnic minorities published until 1989 by the Workers' Association Publishing House "Prasa-Książka-Ruch" (Press-BookMovement). In the case of the German community, these changes did not exist. None of the titles appearing in the Third Republic of Poland originated from a magazine published in the Polish People's Republic [Mieczkowski, 2001, p. 149].

"Wochenblatt.pl" - a journal, which in the first period of its existence, functioned as an appendix to the "Trybuna Opolska" (Opole Tribune). A biweekly bearing the title "Oberschlesische Nachrichten" (Upper Silesian News) debuted on April 20, 1990. This first Polish periodical of the German minority after the transformation of the political system achieved an unbelievable, for that time, circulation of 18 thousand copies.

The task of "Oberschlesische Nachrichten" was to create a counteroffer for the "Schlesische Nachrichten" published in the Federation of Expellees and also distributed in Poland "Schlesische Nachrichten” (Silesian News). The editorial office set up a biweekly with the intention that it would become a bridge between Poles and Germans. Andrew Kracher became the first editor-in-chief of the magazine. Several editions appeared under his headship. The successor to Kracher was Engelbert Miś. They alternated in the role of editor-in-chief.

From October 1993, the newspaper was published every week, and its title was modified to "Oberschlesische Zeitung. Wochenblatt" (Upper Silesian Newspaper. Weekly). The graphic layout also changed.

In 1995, "Schlesisches Wochenblatt" rose through the ranks from a weekly newspaper dealing with the Upper Silesia issue to a newspaper for all Germans in Poland. The periodical expanded its volume and is published until today in weekly mode. From August 1, 2015, the editor-in-chief is Dr. Rudolf Urban [Jas-Koziarkiewicz, 2009, p. 114-116; Richter, 2004, p. 45; Urban, 2018, on-line, Media mniejszości...].

The editorial office uses a bilingual formula, only a few of the articles are printed in one language version, mostly in German. If one of the articles is available in one language version, the other is usually found on the website.

"Wochenblatt" initially consisted of 11 pages, later the number increased to 16 . Only holiday and thematic editions are issued in larger sizes. The title is completed by a colorful TV issue. The current circulation of the magazine is 5,7 thousand copies. The 
newspaper is also available in the form of a subscription as an e-paper on the publishing website.

The title page has not changed much since the beginning of the publication of the weekly. From 2011, however, the title comes only in the German-language version: "Wochenblatt.pl. Zeitung der Deutschen in Polen" (Wochenblatt.pl. A newspaper of Germans in Poland). On the title page there are usually two or three texts dealing with current issues regarding minority activity, politics or society.

Each page of the weekly issued in A4 format (except the first one) has a separate title referring to the issues raised therein: "Meinungen" (Opinions), "Politik und Gesellschaft" (Politics and society), "Aktuelles" (News), "Aus den Regionen" (From regions), "Schlesien" (Silesia), "Allerlei" (Various Matters), "Ratgeber" (Tips), "Wirtschaft" (Economy), "Sport".

"Wochenblatt.pl", as a newspaper of the German minority in Poland, receives support from the Institute for Foreign Cultural Relations based in Stuttgart. Institute, among others, delegates young editors from Germany to work in the Opole editorial office. The periodical is also co-financed by the Ministry of Interior and Administration.

It should be emphasized that the Wochenblatt.pl weekly, as a German minority press, meets all the most important functions sought in the media of national minorities.

"Allensteiner Nachrichten" (Olsztyn News) - a periodical published since 2003 by the Olsztyn Association of the German Minority in A4 format as an 8-page monthly in 450 copies. The subtitle is bilingual. It primarily shows texts in German, the selected ones have a Polish translation, placed in an adjacent column or on the next page. The periodical is available free of charge. The published articles mainly deal with issues related to the activities of the German minority in Olsztyn, present the history of the inhabitants of the former East Prussia, bring closer the legacy of German writers from this region, present publications on the monuments of Olsztyn and Warmia-Masuria Province, deal with the broadly understood German culture. The magazine has an on-line version: www. agdm.pl.

"Antidotum" - a quarterly published in Opole since 2004 by the German Youth Council. The title of the magazine originates in the founding thought of those affiliated to the Council, according to which the periodical was to be free of the influence of major minority activists and was to be a kind of antidote for the passivity of older leaders in matters important to the young generation of Germans in Poland [Mieczkowski, 2007, p. 306-307]. The texts appear in both Polish and German. The 32-page "Antidote" is issued in a circulation of 5.000 copies and is available free of charge. The reader of the quarterly is mainly the youth of the German minority and it is around its interests. Issues raised in the articles oscillate, e.g., by bringing closer known German music groups or outstanding athletes, presenting the latest trends in the fashion world. In the journal, you can also find sections such as "news from Poland and Germany", "from the life of BJDM (Youth Union of the German Minority)" or "strefa studencka" (student's zone). The journal is also available free of charge in an electronic version on the www.issuu.com platform.

"Oberschlesische Stimme - Informations- und Kulturbulletin des Deutschen Freundschaftskreises in der Woiwodschaft Schlesien" (Upper Silesian Voice - Information and cultural bulletin of the German Minority Society in the Silesian province) - newsletter in German published in Racibórz. It has been available since 1991 as a monthly magazine, it is now coming out as a biweekly as part of cooperation with the Opole publisher of the weekly "Wochenblatt.pl" - the "Zespół Producencki Pro Futura " company.

The thematic profile of "Oberschlesische Stimme" has remained practically un- 
changed to this day. The periodical is defined, above all, as a medium dealing with the activities of the German minority in the Silesian province. Articles are published in German.

The biweekly has a A4 format, a volume of about 4 pages and a circulation of 500 copies. The graphic design is colorful. Monika Plura is the editor-in-chief. The journal is also available free of charge in an electronic version at: www.dfkschlesien.pl/pl.

"Danziger Nachrichten" (Gdansk News) - a magazine published in Gdańsk in the years 1992-1996 by the local German Minority Association. It was published irregularly. The function of the editor-in-chief was performed by Thomas Narloch. The periodical was in A4 format, with a volume of 12-14 pages and a circulation of 100-500 copies. The magazine had a black and white graphic design. The newspaper's articles were grouped into the following sections: "Danziger Nachrichten" (Gdansk News), "Geschichte des DFK" (History of the German Minority Association), "Kampf um die Jungen" (Fight for the youth), "Deutsche Minderheiten in Danzig" (German minority in Gdansk), "Bitte Lächeln" (Please smile) [Kalczyńska, 2001, p. 512].

"Elchbote" (Courier Moose) - inherently, a biweekly; it was issued irregularly. It was available in Olsztyn in 1993-1995. The content was in German. The magazine was edited by the "Deutsche Gesellschaft Elch" association (The German Association Moose). The editor-in-chief was Hildegunde Gabriele Butryn. The periodical was in A4 format, the volume was 4-8 pages and it published in 200 copies; the graphic design was black and white and contained illustrations [Mieczkowski, 2007, p. 307].

"Die Heimatkirche" (Homeland Church). Subtitle: "Glaube und Kultur in Schlesien/ Wiara i kultura na Śląsku" (Faith and culture in Silesia) - available since 1995 as a bimonthly in a German-language version in Kolonowskie [Kalczyńska, 2001, p. 513; Mieczkowski, 2007, p. 308]. Currently, the editor-in-chief is Father Dr. Piotr Tarliński. The periodical is in B5 format, with a volume of 8-10 pages and a circulation of several hundred copies. The graphic design is colorful and includes illustrations. The magazine contains interviews, book reviews, news from the life of the German minority in the dioceses of Opole and Gliwice.

"Gleiwitzer Rundblick" (Gliwice Review) - a bimonthly magazine in German language, published in Gliwice since 1998 [Kalczyńska, 2001, p. 513]. The periodical is in B5 format, it has a volume of 8-10 pages and a circulation of 350 copies. It includes reprints from " Gliwice News" and brings closer the figures of well-deserved Gliwice citizens, also including reports on meetings and festivals organized in the region, humor, horoscopes, etc.

“Gruss aus Lomnitz/ Pozdrowienia z Łomnicy” (Greetings from Łomnica) - a semi-annual journal published since 1998 in Łomnica by the Silesian Culture and Art Association. Distributed in a bilingual formula. The periodical is in A4 format, it has 60 pages and is issued in several hundred copies. The graphic design is colorful. The content includes periodic reports on the publisher's activity, a schedule of festivals and celebrations, a presentation of programs and initiatives planned for the following year. The title also aims to introduce the history and outstanding figures associated with the Łomnica region. The editor-in-chief is Karsten Reimann.

"Die Heimatbrücke. Goldaper Heimatbrief" (Bridge to the Motherland. Gołdap Letter to the Homeland) - it has been published in Gołdap since 1998 as a quarterly in German. The publisher was Deutscher Freundschaftskreis Goldap (German Minority 
Association Goldap); currently, it is Kreisgemeinschaft Goldap Ostpreußen e.V. (District Association Goldap East Prussia) [Kalczyńska, 2001, p. 513-514; Mieczkowski, 2007, p. 309]. The magazine comes in a format of $A 4$ and has 40 pages with a colorful graphic design. The periodical provides information about the activities of the organization, the history of Prussia, publishes photographic chronicles and family sagas. The magazine is published in 1,5 thousand copies.

"Hoffnung" (Hope). Subtitle: "Die Deutsche Zeitschrift in Oberschlesien. Czasopismo Niemców na Górnym Śląsku" (German journal in Upper Silesia) - has been published in Katowice since 1993. However, by design, the monthly is issued irregularly. The magazine is created thanks to the German Workers' Association "Pojednanie i Przyszłość" (Reconciliation and the Future) [Jas-Koziarkiewicz, 2009, p. 126-128; Kalczyńska, 2001, p. 513-514; Mieczkowski, 2007, p. 309].. Articles are available in a bilingual formula. The periodical is in A4 format and comes in 5-8 thousand copies with a volume of 8-10 pages. The graphic design is colorful. The contents are sections of: "Politik-Journal" (Political journal), "Kurze Nachrichten" (Information in brief), "Zum Thema” (About the topic), "Diese Seite redagieren unsere Leser" (This page is edited by our readers), "Z notatnika reportera" (From a reporter's notebook), "In Oberschlesien - Na Śląsku” (In Silesia"), "Łosprowski starego Kalusa" (Thoughts of the old Kalus), "Antek und Franzek in O/S" (Antek and Franzek in Upper Silesia), memories, stories, poetry. Until 2000, the magazine had benefited from financial support from the Polish Ministry of Culture.

"Zeszyty Eichendorffa/Eichendorff-Hefte" (Eichendorff's notebooks) - the notebooks are published in Opole by the Upper Silesian Center for Culture and Meetings named after Eichendorff in Łubowice. Fryderyk Wilhelm Kremser was the first editor-in-chief. At present, this post is held by Prof. dr. hab. Joanna Rostropowicz. The notebooks appeared for the first time in 1993 and are still issued quarterly today. They are of A5 format, the circulation is $1-1,2$ thousand copies. The graphic design is colorful and presents illustrations and photographs. The first copy of the notebooks appeared in Polish; since the second issue, they are available in bilingual formula. The periodical originally amounted to a dozen pages in volume; currently, it ranges between 120 and 170 pages. The notebooks deal with issues related to the German traces in the cultural heritage of Silesia. Historical, ethnographic and literary issues are included in the form of historical essays, poetry and fragments of stories. The notebooks are issued with the support of the German General Consulate in Wrocław and the Ministry of Culture and National Heritage.

"Masurische Storchenpost" (Masuria Stork Post) - it has been published in Olsztyn since 1990 [Kalczyńska, 2001, p. 514; Mieczkowski, 2007, p. 310]. The monthly is published in German. The publisher is the Mazurian Association. The position of the editor-in-chief is held by Tadeusz Willan. The magazine is in A5 format; it has 44 pages of volume and is published in 500 copies.

The periodical describes the current events relevant from the perspective of the German national minority - both national (especially regional) as well as foreign ones. It publishes, among others, distinctions of meritorious persons for the benefit of minorities, cultural, artistic and social events, case seminars, congresses, associations and ethnic groups (especially the Union of German Associations in former East Prussia). Above all, the title relates the activities of the founding organization, i.e., the Mazurian Association, being its body.

The readers of "Masurische Storchenpost" are mainly residents of Warmian-Masurian voivodeship. The periodical is also distributed among others to Austria, Belgium, Denmark, France, Germany, the United States, Lithuania and Hungary, where he finds 
readers among Mazurians who left Poland after World War II.

The periodical is created with the co-funding of the Polish Ministry of Culture and National Heritage and the German General Consulate in Gdańsk.

Mitteilungsblatt der deutschen Gesellschaften in Ermland und Masuren (Bulletin of German Societies in Warmia-Masuria Province). The periodical is published in Olsztyn as a monthly by the Union of German Associations in former East Prussia. The magazine comes in A4 format, it has 20 pages of volume and is published in about 1 thousand copies. The graphic design is colorful, contains illustrations and photographs. The magazine is available on-line at www.zsnwim.eu. Until 1997, the content was published only in German; since 1998, more important texts also appear in Polish. The content mainly includes cultural news from the activities of the Socio-Cultural Association of the German Minority in Warmian-Masurian voivodeship, correspondence, reprints from the Polish and German press, comments and small ads.

The periodical uses financial support from the German General Consulate in Gdańsk and subsidies from the Polish Ministry of Culture and National Heritage.

"Niederschlesische Informationen" (Lower Silesian Newsletter). Subtitle: "Zeitschrift der Deutschen Sozial-Kulturellen Gesellschaft in Breslau" (Periodical of the German Socio-Cultural Association in Wrocław) - a semi-annual journal in German, published in Wrocław since 1998 [Kalczyńska, 2001, p. 515; Mieczkowski, 2007, p. 312]. The periodical is in A4 format, in a volume of 12-14 pages and an issue of 500 copies. The graphic design is colorful, illustrations and photographs are published in it. The content of the journal consists of a political review, reports on the Association's activities, historical facts, cultural, religious and social information, and poetic works. The publication is created with the co-financing of the German General Consulate in Wroclaw, the Institute for Foreign Cultural Relations in Stuttgart, Foundation of the Silesia Development and the Ministry of Interior and Administration. Until 2009, the quarterly was published under the title: "Niederschlesisches Informationsblatt" (Lower Silesian Newsletter).

"Oberschlesisches Bulletin" (Upper Silesian Newsletter) - a magazine published in Bytom since 1993 [Kalczyńska, 2001, p. 515; Mieczkowski, 2007, p. 313]. Formally, it is a bimonthly, however it comes out irregularly. The publisher of the periodical is the Association of Authors and Artists of German Minorities in Poland. It is in A4 format, the volume is 4-6 pages, and it is issued in 50-100 copies. The content is divided into sections: "Kommentar" (Commentary), "Gedichtband" (Poems), "Vortragszyklus" (Lecture series), "Literarisches" (Literary). The periodical uses the subsidy of the Federal German Consulate in Wrocław and the Ministry of Culture.

"Osteroder Rundbrief" - the publisher of the monthly was the Association of the German Minority "Jodły" (Firs) in Ostróda, which was published in German in the years 1994-1996. The functions of the editor-in-chief were performed by Józef Lamcho. The journal was published in 100 copies [Kalczyńska, 2001, p. 515].

"Pomeranus - Informationsblatt" (Pomeranus - Newsletter) - the periodical was published in Szczecin in 1991-2000. Formally, it was a monthly, however, it was also published as a bimonthly or quarterly. The first copies were published in Polish, and later, a bilingual formula was adopted. In 1995 Alfons Bobek became the editor-in-chief. At that time, it was decided to keep the journal in German language only. The publisher was the Socio-Cultural Association of the German Minority in Szczecin. The periodical was in A4 format, with a volume of 4-8 pages and an issue of 100 copies. The graphic design was 
black and white. The magazine mainly discussed issues related to the activities of the Association. The core of the publication was news about the projects and celebrations organized by the German minority, announcements of German minority associations were also printed [Mieczkowski, 2007, p. 313-315].

"Ratiborer Mitteilungen - Raciborskie Wiadomości" (Racibórz News) - the journal was appearing from 1999 to 2012 in Racibórz as the body of the German Student Union. It came in A4 size, initially it had 8 pages in black and white; from 2003, it was also enriched with a colorful graphic design. Copies from 2012 had 22 pages. The theme of the news was connected, above all, with the activity of the Union. It was also possible to find information on the cultural heritage and history of the region, reviews and reports on conferences and student meetings organized both in the country and abroad. Periodicals from 2002-2012 are also available in electronic form on the website of the Union: www.vdh-ratibor.vdg.pl.

"Thorner Bote - Goniec Toruński" (Toruń Courier) - the periodical has been published in Torun since 1996. It had the status of a semi-annual and was published in German. The publisher was the German People's Union in Toruń. The journal was in A4 format, with a volume of 12 pages and an issue of 500 copies. The graphic design was black and white. "Thorner Bote" first of all presented the effects of the Union's work. Its pages also contained literature, cultural information, cinema repertoire, theater, book criticism, etc. [Kalczyńska, 2001, p. 516].

"Unser Rauden" (Our Rudy) - a periodical in German, issued in Rudy since 1996. The publisher was the local Socio-Cultural Association of the German Minority. The periodical had the status of a monthly magazine, available in A5 format, 16 pages of volume and 200-500 copies. The graphic design was black and white, photographs and illustrations were presented there. In the monthly, you could find news about the Association's projects, stories and poetry [Mieczkowski, 2007, p. 316].

“Miesięcznik Zielonogórski - Grünberger Monatsblatt” (Zielonagóra Monthly) newspaper of the Socio-Cultural Association of the German Minority in Zielona Góra. The periodical has been issued since 2006 in paper and electronic form. The monthly initially had 6 , and currently 12 color pages of volume. Distributed in a bilingual version - Polish-German. The contents of the magazine are: poetry, information about meetings and cultural, religious and social events, information on the activities of the Society, historical news. Illustrations and photographs are included in it. All issues of the monthly are also available free of charge in an electronic version on the Association's website: wwww.tskmn.pl.

"KEKS für die Pause/na przerwę" (Biscuit for the break) - a Polish-German magazine for grades IV - VI. The magazine is a colorful 16-page, free of charge periodical with an edition of 8.000 copies issued since 2013 by the House for Polish-German Cooperation in Opole. The newsletter informs about upcoming meetings and cultural workshops, introduces important figures of the world of literature, culture and history. The magazine's constant components are reading materials for learning German with glossary, comics, tasks, puzzles and crosswords. The periodical is co-financed by the Ministry of the Interior of the Federal Republic of Germany. It has an on-line version: www.bilingua.haus.pl. 
REFERENCES:

\section{Source materials:}

Ustawa o mniejszościach narodowych i etnicznych oraz o języku regionalnym z dnia 6 stycznia 2005 r. (Dz. U. Nr 17, poz. 141, z późn. zm.)

Konstytucja Rzeczypospolitej Polskiej z dnia 2 kwietnia 1997 r. - (Dz.U. 1997 nr 78 poz. 483)

Ustawa z dnia 11 marca 2004 r. o podatku od towarów i usług (Dz. U. nr 54, poz. 535 z późn. zm.) art. 146)

Ustawa z dnia 4 marca 2010 r. o narodowym spisie powszechnym ludności i mieszkań w 2011 r. (Dz.U. 2010 nr 47 poz. 277)

Ustawa z dnia 2 grudnia 1999 r. o narodowym spisie powszechnym ludności i mieszkań w 2002 r. (Dz. U. Nr 1, poz. 1, z późn. zm.)

Ustawa z dnia 29 grudnia 1992 r. o radiofonii i telewizji. (Dz. U. z 2004 r. Nr 253, poz. 2531, z późn. zm.)

Ministerstwo Spraw Wewnętrznych i Administracji (2007), Raport dotyczacy sytuacji mniejszosci narodowych i etnicznych oraz jezyka regionalnego w Rzeczypospolitej Polskiej - 2007

Ministerstwo Spraw Wewnętrznych i Administracji (2018), V Raport dotyczący sytuacji mniejszości narodowych i etnicznych oraz języka regionalnego w Rzeczypospolitej Polskiej - 2015

\section{Literature:}

BERDYCHOWSKA B. (1995), Wobec mniejszości [in:] Społeczeństwo otwarte. Miesięcznik Ministerstwa Edukacji Narodowej, vol. 4, Warszawa, Ministerstwo Edukacji Narodowej.

BINGEN D., MALINOWSKI K. (2000), Polacy i Niemcy na drodze do partnerskiego sąsiedztwa,

Poznań, Instytut Zachodni.

BOJAR H. (2000), Mniejszości społeczne w państwie i społeczeństwie III Rzeczypospolitej Polskiej, Wrocław, Wydawnictwo Funna

JAS-KOZIARKIEWICZ M. (2009), Podróże po mniejszym niebie. Dotowane pisma mniejszości niemieckiej w Polsce jako prasa środowiskowa po 1989 roku, Warszawa, Oficyna Wydawnicza Aspra-Jr;

KALCZYŃSKA M. (2001), Adnotowana bibliografia czasopism wydawanych przez mniejszość niemiecką w Polsce oraz organizacje współpracujące (1990-1999). [in:] Komunikaty Mazursko-Warmińskie, vol. 3, Olsztyn, Ośrodek Badań Naukowych im. Wojciecha Kętrzyńskiego.

KLIMKIEWICZ B. (1997), Media mniejszości w Polsce [in:] Wilkanowicz S. (ed.), Konflikt czy współdziałanie. Media a problem mniejszości, Kraków, Fundacja Kultury Chrześcijańskiej.

KOJDER A., BOKSZAŃSKI Z. (1998), Encyklopedia socjologii, vol 2, Warszawa, Oficyna Naukowa

KRUSZEWSKI T. (2008), Współczesna prasa mniejszości etnicznych w Polsce w przestrzeni społecznej - wybrane obszary [in:] Toruńskie Studia Bibliologiczne, vol. 1, [on-line: May 09, 2018], http://apcz.umk.pl/czasopisma/index.php/TSB/article/view/TSB.2008.003

KURASZ I. (2014), Media ludności niemieckiej Dolnego Śląska na tle przeobrażeń politycznych, społecznych i demograficznych w latach 1950-2013 [in:] Studia humanistyczne AGH, vol. 13, [on-line: January 5, 2018], http:// journals.bg.agh.edu.pl/STUDIA/2014.13.3/human.2014.13.3.81.pdf

ŁOZIŃSKI S. (1999), Polskie regulacje prawne dotyczące mniejszości narodowych i cudzoziemców na tle zasad polityki wielokulturowości, vol. 14-15, [in:] Sprawy narodowościowe. Seria Nowa. Warszawa, Instytut Slawistyki Polskiej Akademii Nauk.

ŁODZIŃSKI S. (2005), Równość i różnica: mniejszości narodowe w porządku demokratycznym w Polsce po 1989 roku, Warszawa, Wydawnictwo Naukowe Scholar.

MADAJCZYK P. (2001), Niemcy polscy 1944-1989, Warszawa, Oficyna Naukowa.

MALICKA A. (2018), Status prawny mniejszości narodowych i etnicznych w Polsce - ustawa o mniejszościach narodowych i etnicznych oraz języku regionalnym. Wroclaw, [on-line: February 03, 2018], http://www.repozytorium.uni.wroc.pl/publication/94626

MIECZKOWSKI J. (2001), Media mniejszości narodowych w Polsce po 1989 roku charakterystyka działań [in:] Burger W., Etniczne odsłony pogranicza. Rozprawy i Studia, Szczecin, Wydawnictwo Naukowe Uniwersytetu Szczecińskiego.

MIECZKOWSKI J. (2001), Prasa mniejszości narodowych i etnicznych w polityce państwa polskiego od 1989 roku charakterystyka działań [in:] Burger W., Etniczne odsłony pogranicza. Rozprawy i Studia, Szczecin, Wydawnictwo Naukowe Uniwersytetu Szczecińskiego. 
MIECZKOWSKI J. (2007), Prasa mniejszości narodowych i etnicznych w polityce państwa polskiego od 1989 roku. Szczecin, Wydawnictwo Naukowe Uniwersytetu Szczecińskiego.

MATELSKI D. (1999), Niemcy w Polsce w XX wieku, Warszawa, Wydawnictwo Naukowe PWN.

OCIEPKA B. (1994), Niemcy na Dolnym Śląsku w latach 1945-1970, Wrocław, Wydawnictwo Uniwersytetu Wrocławskiego.

PISAREK W. (1983), Analiza zawartości prasy, Kraków, Ośrodek Badań Prasoznawczych.

RICHTER S. (2004), Das Schlesische Wochenblatt unter der Luppe [in:] Deutschsprachige Medien in Mittel- und Osteuropa. Berichte und Analysen, vol 1, Stuttgart, Institut für Auslandbeziehungen e. V. Dokumente.

SAKSON, A. (2012), Mniejszość niemiecka na Śląsku w świetle Narodowego Spisu Powszechnego z 2011 r. [in:] Biuletyn Instytutu Zachodniego, vol. 85, Poznań, Instytut Zachodni w Poznaniu.

STOLARCZYK M. (1996), Problem Górnego Ślaska w kontekscie stosunków polsko-niemieckich [w:] Przegląd Zachodni, vol. 4 , Poznań, Instytut Zachodni.

SzMEJA M. (2000), Niemcy? Polacy? Ślązacy! : rodzimi mieszkańcy Opolszczyzny w świetle analiz socjologicznych, Kraków, Universitas

URBAN R. (2018), Media mniejszości niemieckiej w Polsce [on-line: January 5, 2018], http://www.polska-niemcy-interakcje.pl/articles/show/24

ZYBURA M. (2001), Niemcy w Polsce, Wrocław, Wydawnictwo Dolnośląskie.

\section{Websites:}

Ministerstwo Spraw Wewnętrznych i Administracji (2018), Charakterystyka mniejszości narodowych i etnicznych w Polsce [on-line: January 5, 2018], http://mniejszosci.narodowe.mswia.gov.pl/mne/mniejszosci/ charakterystyka-mniejs/6480,Charakterystyka-mniejszosci-narodowych-i-etnicznych-w-Polsce.html\#niemcy

Kancelaria Sejmu (2018), Posłowie [on-line: January 5, 2018], http://www.sejm.gov.pl/Sejm7.nsf/posel. xsp?id=092

Ministerstwo Spraw Wewnętrznych i Administracji (2018), Dotacje [on-line: January 5, 2018], http://mniejszosci.narodowe.mswia.gov.pl/mne/dotacje

Allensteiner Nachrichten [on-line: December 15, 2017], http://leksykonkultury.ceik.eu/index.php/ Allensteiner_Nachrichten

Masurische Storchenpost, [on-line: December 12, 2017], http://leksykonkultury.ceik.eu/index.php/Masurische_ Storchenpost

BJDM znów ma swoje pismo [on-line: December 10, 2017], http://www.nto.pl/serwisy/heimat/art/4469101,bjdm-znow-ma-swoje-pismo,id,t.html

Deutsche Sozial-Kulturelle Gesellschaft in Breslau, [on-line: December 11, 2017], http://archive. is/20130830132239/www.ntkswroclaw.vdg.pl/de/deutsch-minderheit-in-polen/deutsche-sozial-kulturelle-gesellschaft-in-breslau

Antidotum, [on-line: December 9, 2017], http://www.udyomedia.pl/def-Antidotum_(kwartalnik).html

20 lat TSKN na Ślasku Opolskim, [on-line: December 9, 2017], http://skgd.pl/wp-content/uploads/2016/02/20Jahre-der-SKGD-im-Oppelner-Schlesien-Deutsche-in-Oppeln-seit-1989-bis-heute.pdf

Masurische Storchenpost, [online: December 17, 2017], https://ermlandmasuren.wordpress.com/tag/masurische-storchenpost/

www.zsnwim.eu [on-line: December 16, 2017],

www.wochenblatt.pl [on-line: January 5, 2018]

www.bilingua.haus.pl [on-line: January 5, 2018]

www.eichendorff.pl [on-line: January 3, 2018]

www.agdm.pl [on-line: January 5, 2018]

http://smn-tannen.vdg.pl [on-line: December 18, 2017],

http://www.vdh-ratibor.vdg.pl [on-line: December 17, 2017],

http://vskschlesien.de [on-line: December 16, 2017],

http://www.goldap.de [on-line: December 21, 2017],

http://www.deutschegem.eu [on-line: December 20, 2017] 